\title{
シェーグレン症候群における喠液腺組織障害の分子機構
}

小川 法 良，下山久美子，河 南 崇 典

\section{Molecular mechanisms of salivary gland destruction in patients with Sjögren's syndrome}

\author{
Noriyoshi Ogawa, Kumiko SHImoyama and Takafumi KawanAmi \\ Department of Hematology and Immunology, Kanazawa Medical University
}

(Received December 28, 2004)

summary

IFN $\gamma$ plays an important role to induce several functional molecules on salivary epithelial cells, including class II MHC, Fas and CD40 in salivary glands from patients with Sjögren's syndrome (SS). IFN $\gamma$ also contributes to the development of lymphocytic infiltrates by inducing $\mathrm{T}$ cell attracting chemokines in SS salivary epithelial cells, such as IP10 (CXCL10), Mig (CXCL9), and I-TAC (CXCL11). IFN $\gamma$ dysregulation in SS salivary gland may attribute to the decreased production of TGF $\beta$ from salivary epithelial cells in some patients. Expression of Fas and CD40 was significantly higher in SS salivary epithelial cells than in normal cells after IFN $\gamma$ stimulation. Although neither anti-Fas (CH11) nor anti-CD40 mAb alone could induce typical apoptosis, the two together and preincubation with IFN $\gamma$ efficiently induced apoptosis in SS salivary epithelial cells. This apoptosis was almost completely blocked by neutralizing anti-Fas mAb (ZB4) . c-FLIP, an important inhibitory molecule in the Fas death pathway, was strongly expressed in SS salivary epithelial cells, but its expression was downregulated, at the protein level, by anti-CD40 mAb. CD40 signals promote Fas-dependent death of SS salivary epithelial cells by downregulating c-FLIP expression. The presence of cFLIP in these cells may explain their resistance to undergo apoptosis in response to either anti-Fas or anti-CD40 mAb, despite their surface expression of both proteins. These findings suggest that SS salivary epithelial cell death requires the cooperation of Fas and CD40.

Key words_ cytokine; chemokine; apoptosis; Fas; CD40

\section{抄 録}

シェーグレン症候群（SS）唾液腺において産生されるサイトカインでは浸潤リンパ球由来の IFN $\gamma$ が重要である と考えられ， class II MHC，Fas，CD40など様々な機能分子を上皮細胞に発現誘導する。一部の患者では IFN $\gamma$ の 過剰産生の理由として上皮細胞から産生される TGF $\beta$ の産生減少が関与していることが示唆された. また SS 唾液 腺において産生される主な T 細胞遊走性ケモカインは IFN $\gamma$ により唾液腺上皮細胞に誘導される IP-10 (CXCL10), Mig (CXCL9)，I-TAC (CXCL11) であった. SS 唾液腺においては上皮細胞が Fas を発現し，浸潤リンパ球の一部 が FasL を発現している. SS 唾液腺培養上皮細胞は IFN $\gamma$ 刺激により Fas 発現が増大するが，この状態で抗 Fas 抗 体を作用させても細胞死は誘導されなかつた．同時に発現が増大する CD40に対する抗体を抗 Fas 抗体とともに添 加すると効率的に細胞死が誘導された. この細胞死はアポトーシスであり, 抗 Fas 中和抗体にて抑制されるため, 主に Fas 経路を介するものであると考えられた．CD40 からの刺激は恒常的に発現している細胞死抑制蛋白である c-FLIP 発現を抑制することにより, Fas の経路を促進していることが示唆された.

はじめに

シェーグレン症候群（SS）は代表的自己免疫疾 患の一つであり，ヒトのリウマチ性疾患の中では関 節リウマチについで患者数が多く，まれな疾患では ない1)。臨床的には涙腺，唾液腺における慢性炎症

金沢医科大学血液免疫制御学
によってドライアイ, ドライマウスを生じ, QOL の低下をきたす。症例によっては，胆汁性肝硬変， 腎尿細管性アシドーシスなど多彩な臓器病変を呈す る2). 他のリウマチ性疾患同様, 未だその病因, 病 態は不明である。

病因，病態に基づいた SS に対する特異的治療は 今のところ存在しないが，本症候群の主な症状であ る口腔乾燥症状に対しては副交感神経刺激薬である 
塩酸セビメリンを主とする対症的治療がなさ れ ${ }^{3,4)}$, 一部の重篤な腺外症状に対しては副腎皮質 ステロイド剤や免疫抑制剤が投与される ながら腺機能がほとんど廃絶した乾燥症状に対する 決定的な治療は存在せず，悪性リンパ腫の発症頻度 が健常人にくらべて有意に高率であるため免疫抑制 療法が施行しにくいなどの問題点を持っている6).

SS 唾液腺における顕著な病理学的変化はリンパ 球からなる細胞浸潤の存在である。これまでは慢性 炎症，すなわち浸潤細胞が上皮細胞障害をもたらし 唾液腺機能低下が進行するものと考えられてきた. しかしながら唾液腺機能障害のメカニズムは，従来 考えられていたより複雑であり，また多因子による 可能性が指摘されるようになっている，代表的なも のをあげるだけでも，炎症性細胞浸潤による機序の ほか, サイトカインのバランス異常7)，M3 ムスカ リン受容体に対する自己抗体の存在や受容体の反応 性低下8)，アクアポリンの分布異常 ${ }^{9)}$, matrix metalloproteinase (MMP) による腺構造の破壊など が指摘されている10).

著者らは現在までに SS 唾液腺における病理学的 変化を解明するために, サイトカイン, ケモカイ ン, アポトーシスについて解析を進めてきた．本稿 では，自験結果を中心に現在までに判明している SS 唾液腺組織障害の分子機構を概説する.

\section{1. サイトカイン}

SS 唾液腺におけるサイトカイン産生については これまでに多くの報告がなされているが11 18)，見 解の一致がみられていない。この理由として, 国際 的に通用する診断基準を欠くことによる対象患者の 相違, 対象藏器の相違 (大唾液腺と小唾液腺), サ イトカインの検出手法の相違, またステロイド剂等 の治療などが結果に影響を与えている可能性が示唆 される，著者らの検討では ${ }^{13)}$ ，口唇小唾液腺を用い た RT-PCR 法による解析にて IL- $1 \alpha, \mathrm{IL}-1 \beta, \mathrm{IL}-2$, IL-6，IL-10，IFN $\gamma ， T G F \beta$ などの mRNA が発現し ており, 中でも IL-2, IL-6, IL-10の発現率は focus score の増大に伴って増加していた。一方, TGF $\beta$ は focus score の増大につれて mRNA 発現が 低下する傾向が認められた。ささらにELISA 法を用 いた唾液腺上皮細胞の培養上清中の蛋白レベルでの 解析により, TGF $\beta$ は focus score の高い例で産生 が減少していた。 TGF $\beta$ は免疫組織染色において主 に上皮細胞が産生していることが示され，同様に

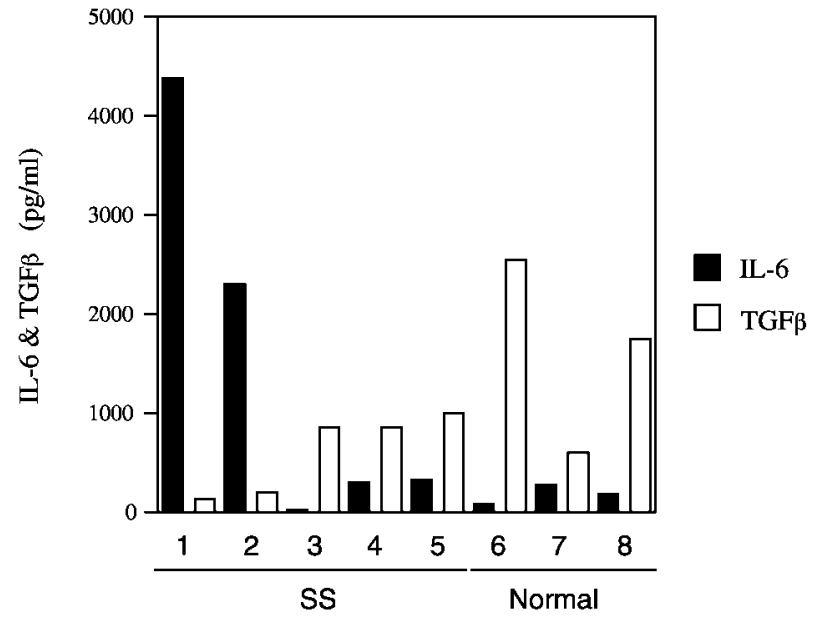

図 1 IFN $\gamma$ 刺激培養唾液腺上皮細胞による IL-6 抢よび $\mathrm{TGF} \beta$ の産生

SS 5 例, 正常 3 例における検討結果を示す. SS および正 常唾液腺上皮細胞を IFN $\gamma(1000 \mathrm{U} / \mathrm{ml})$ の存在下で 6 日間培 養し, 上清中のサイトカインレベルを ELISA 法にて測定し た．SS に扔いて高 IL-6 産生を示す例を認め，そのような例 では TGF $\beta$ 産生が減少している傾向が認められた.

focus score の増大とともに同部位での発現が低下 していた。近年, 新たに開発した無血清培養法を用 いて改めて培養唾液腺上皮細胞を検討した結果, $\mathrm{SS}$ 唾液腺上皮細胞は IFN $\gamma$ 刺激により大量の IL-6 産生を示し, これとは逆に TGF $\beta$ の産生が減少し ている傾向が認められた（図 1).

$\mathrm{SS}$ 唾液腺における $\mathrm{TGF} \beta$ 発現低下の意義を検討 するため, TGF $\beta 1$ ノックアウトマウスの解析を行 った. TGF $\beta 1$ ノックアウトマウスは生後数週間で 唾液腺を含む全身の諸臓器に炎症を生じ, wasting syndrome を呈して死に至る19)。まず，TGF $\beta 1$ ノッ クアウトマウスにおいて, その血清中に抗 DNA 抗 体等の自己抗体の産生が認められることを, ELISA 法およびウエスタンブロット法で確認し た ${ }^{20)}$. 次に, このマウスの唾液腺において $\mathrm{IL}-1 \alpha$, IL-1 $\beta$, IL-2, IL-4, IL-6, IL-10, IFN $\gamma$ などのサイト カインや ICAM-1, VCAM-1 などの接着因子, class II MHC 抗原の異常発現を見いだした ${ }^{21)}$. TGF $\beta 1 /$ class II MHC ダブルノックアウトマウスで は, これらのサイトカイン, 接着因子の発現やリン パ球浸潤が認められない21)ことより, TGF $\beta 1$ の欠 損が唾液腺における class II MHC 抗原の異常発現 を惹起し, 炎症性病変を引き起こす可能性が示唆さ れた。

現在，著者らは SS 唾液腺において産生されるサ イトカインとして浸潤リンパ球からの IFN $\gamma$ が重要 と考えている. IFN $\gamma$ は唾液腺上皮細胞に class II 
$\mathrm{MHC}^{22)}$ ，Fas および $\mathrm{CD} 40^{23)}$ ，副刺激分子 ${ }^{24)}$, $\mathrm{iNOS}^{25)}$ など病態に関わる主要な分子の発現を増大 させ，後述のごとく，上皮細胞のアポトーシス誘導 にも密接に関連している. SS 唾液腺において IFN $\gamma$ が異常発現する理由の一つに上皮細胞からの TGF $\beta$ 産生減少が関与している可能性が考えられる. 実際,

$\mathrm{TGF} \beta$ 産生減少は IFN $\gamma$ の細胞内伝達系を促進する ことが報告されており病因を考えるうえで興味深 い26). TNF については阻害療法が効果を示さない ことから 27)，少なくとも SS 唾液腺における役割は 中心的なものではないと考えられる.

以上より, SS 唾液腺におけるサイトカインにつ いては IFN $\gamma$ 等の炎症性サイトカインと TGF $\beta$ 等の 抗炎症性サイトカインのバランスに異常を来してい る可能性が示唆される。.すなわち SS においては自 己抗原に反応したリンパ球が IFN $\gamma$ 等の炎症性サイ トカインを産生しやすく, 一方，上皮細胞は TGF $\beta$ 等の抗炎症性サイトカインを産生しにくいという背 景の両方またはどちらか一方を持っていることが示 唆される。これにより，自己抗原の class II MHC 上への抗原提示が促進されたり，炎症が終息せず持 続してしまう可能性があるのではないかと推察して いる.

\section{2. ケモカイン}

$\mathrm{SS}$ 唾液腺に生じる細胞浸潤は初期には $\mathrm{T}$ 細胞優 位であり, 病期の進展とともに $\mathrm{B}$ 細胞が増加す る. マクロファージや NK 細胞はまれである. SS 唾液腺における細胞浸潤の形成にはサイトカインや 接着因子が関与していることが知られているが，そ の詳細なメカニズムは不明である。炎症性細胞浸潤 形成にはケモカインが重要な役割を果たしている.

SS の病変局所におけるケモカインに関する研究は 既にいくつか報告されている28 32)．著者らは 4 種 類の $\mathrm{T}$ 細胞遊走性ケモカイン, IP-10 (CXCL10), Mig (CXCL9), SDF-1 (CXCL12), I-TAC (CXCL11) について検討した ${ }^{33 \sim 35)}$.

口唇小唾液腺組織より RNA を分離し, RT-PCR 法にて上述のケモカイン mRNA の発現を解析した ところ, SS 唾液腺において IP-10, Mig, I-TAC の 強い発現が認められた ${ }^{34,35)}$ 。一方, SDF-1 の発現 はSS および正常唾液腺において同程度であった。

次に免疫組織染色法を用いて, SS 唾液腺におけ るこれらケモカイン産生細胞の同定を行った（図 $2 a, b, c)$. SS 唾液腺では導管上皮細胞が IP-10,
Mig, I-TAC を強く発現していた. これらのケモカ インはとりわけ周囲に強い細胞浸潤を伴っている導 管に強く発現していた.

同様に, IP-10, Mig, I-TAC に対するレセプター である CXCR3，および SDF-1 に対するレセプ ターである CXCR4 の SS 唾液腺における発現を免 疫組織染色法により検討したところ, 唾液腺浸潤細 胞は細胞浸潤の強い部位（dense foci）では大部分 が CXCR3 陽性であり, 比較的浸潤がまばらな部位 では CXCR4 陽性細胞が多数を占めていた（図 2d, e)。CXCR3 陽性細胞はほとんどが CD3 陽性 T 細 胞であった.

以上より, SS 唾液腺においては, 導管上皮細胞 が IP-10, Mig, I-TACを産生し，これに対して CXCR3 を発現した活性化 $\mathrm{T}$ 細胞が集族し, 細胞浸 潤を形成するメカニズムが示唆された.

周囲に細胞浸潤を伴う導管に強いケモカインの発 現が認められたことより, 導管周囲の浸潤細胞から 何らかのケモカイン産生促進因子が分泌されている 可能性が考えられた。これを調べるため, 唾液腺上 皮細胞を IFN $\gamma$ 存在, 非存在下で 12 時間培養し, RT-PCR 法にてケモカイン mRNA の発現を解析し たところ, IFN $\gamma$ は SS, 正常唾液腺上皮細胞の両者 に IP-10, Mig, I-TAC の発現を誘導した ${ }^{34,35)}$.

また IFN $\gamma$ 非存在下では SS, 正常唾液腺上皮細 胞ともにケモカイン (IP-10, Mig, I-TAC) の産生 を認めなかったが, IFN $\gamma$ を添加するとこれら 3 種 類のケモカインの培養上清中への産生が認められ $た^{34,35)}$. 興味深いことに, IFN $\gamma$ 誘導性ケモカイン の mRNA 発現は SS, 正常唾液腺上皮細胞間で差を 認めなかったのにも拘わらず，上清中のケモカイン 産生は SS 唾液腺上皮細胞において六進していた。 IFN $\gamma$ 以外に SS 唾液腺上皮細胞にこれらのケモカ インを誘導するサイトカインがあるかどうかを検討 するために, SS 唾液腺における発現が報告されて いる IL-1 $\beta, \mathrm{IL}-4, \mathrm{IL}-6, \mathrm{IL}-10, \mathrm{TNF} \alpha$ および TGF $\beta$ を用いて, IP-10, Mig, I-TAC 発現に与える影響を RT-PCR 法にて解析したが, IFN $\gamma$ 以外では TNF $\alpha$ が IP-10 の発現を誘導したのみであり ${ }^{34,35)}$ ，ここで も SS 唾液腺における IFN $\gamma$ の重要性が示唆されて いる.

以上より, SS 唾液腺における IP-10, Mig, I$\mathrm{TAC}$ などの $\mathrm{T}$ 細胞遊走性ケモカインの産生には IFN $\gamma$ が重要な役割を果たしていることが示唆され, $\mathrm{SS}$ 唾液腺上皮細胞は IFN $\gamma$ に対するケモカイン産 

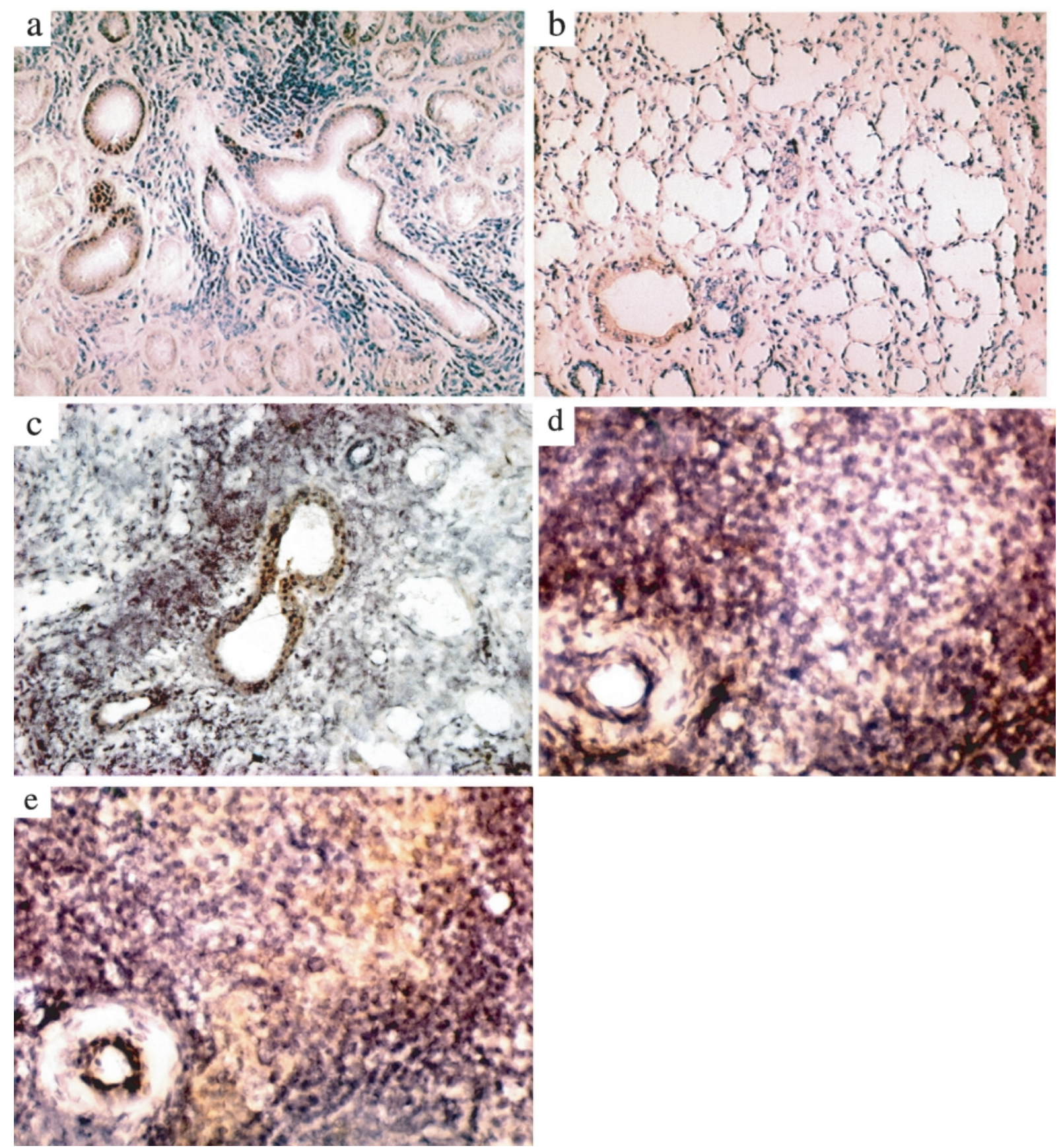

図 2 SS 唾液腺に打ける (a) IP-10，(b) Mig，(c) I-TAC，(d) CXCR3，(e) CXCR4の発現 免疫組織染色法によりいずれのケモカインも周囲にリンパ球浸潤が著明な導管上皮細胞に発現が認められた。一方， dense foci では主に CXCR3 陽性細胞が多く，まばらな部位では CXCR4 陽性細胞を多く認めた。

生反応が充進しており，これは上皮細胞の活性化を 反映する所見ではないかと推察している.

また著者らはリンパ球のケモカインレセプター発 現に対するIFN $\gamma$ の影響について検討した ${ }^{34)}$ 。分離 した末梢血リンパ球を IFN $\gamma$ とともに 12 時間培養 し，CXCR3 および CXCR4 発現をRT-PCR 法に て検討したところ，IFN $\gamma$ は CXCR3 の発現を増大 させたが，CXCR4の発現は誘導しなかった。この CXCR3 mRNA 発現の増大は細胞表面の CXCR3
発現の増大を引き起こした ${ }^{34)}$. 発現した CXCR3 は 機能的であることが遊走能実験にて確認されてい る。すなわち, IFN $\gamma$ は $\mathrm{T}$ 細胞遊走性ケモカインを 導管上皮細胞に誘導するだけでなく, リンパ球にこ れらケモカインに対するレセプターである CXCR3 の発現を誘導することが判明した。

3. アポトーシス

アポトーシスは元来形態学的に定義された概念で 
あり，細胞壞死（ネクローシス）と対照的な細胞死 の様式である．アポトーシスに陥つた細胞は収縮 し，核が濃縮，断片化する。断片化した核は細胞膜 に包まれ，アポトーシス小体を形成し，食細胞によ り処理される．この過程は一連の遺伝子により制御 され，エネルギーを消費し能動的に遂行される，ネ クローシスと異なり原則的に炎症を惹起しないとい う性質により, 生体内の細胞環境のホメオスターシ スを維持する重要なメカニズムである，胸腺におけ る自己反応性 $\mathrm{T}$ 細胞の選択的除去（ネガテイブセ レクション）はアポトーシスによって行われる事実 により示されるごとく, 自己免疫疾患の病因, 病態 に深く関わっている36,37).

SS の病変局所および未梢血リンパ球におけるア ポトーシスに関する研究は著者らを含め, 数多く報 告されている38 53)。ここでは主に SS 唾液腺組織お よび上皮細胞におけるアポトーシスにつき，著者ら の成績を中心に述べる.

SS 唾液腺組織におけるアポトーシスについて 調ベるために，アポトーシス細胞を Terminal deoxynucleotidyl transferase dUTP nick end labeling （TUNEL）法により検出した ${ }^{38)}$.SS においては唾 液腺浸潤リンパ球のうち, アポトーシスに陥つた細 胞は散在性の細胞浸潤部位で多く, 細胞浸潤の強い 部位（dense foci）では少なかった。腺細胞におい ては，導管上皮及び腺房細胞にアポトーシス細胞を 認めた．正常唾液腺組織では，導管上皮にのみ少数 のアポトーシス細胞を認め，これは正常の上皮細胞 の turnover を反映する所見と考えられた.

免疫組織染色により Fas/FasL の発現を検討した ところ ${ }^{38)}$ ，浸潤リンパ球の大部分及び導管上皮，腺 房細胞が Fas を発現していた，Fas の染色性は上皮 より浸潤リンパ球の方が強く, また Fas 陽性の導 管細胞は dense foci の近傍に認められる傾向があっ た. FasL は浸潤リンパ球の一部に発現を認めた. 正常唾液腺組織では腺房細胞が Fas 陽性であり,

FasL の発現は認めなかった。

また Bcl-2 の発現について免疫組織染色により解 析を行った ${ }^{399}$. SS 唾液腺では大部分の浸潤リンパ 球が Bcl-2 陽性であり, 導管細胞にも Bcl-2 陽性細 胞が認められた．正常唾液腺組織では組織中及び血 管内に存在した少数の単核細胞が Bcl-2 陽性であっ た.

以上をまとめると，SS 唾液腺においては 1）上 皮細胞にアポトーシスが認められ，浸潤リンパ球で

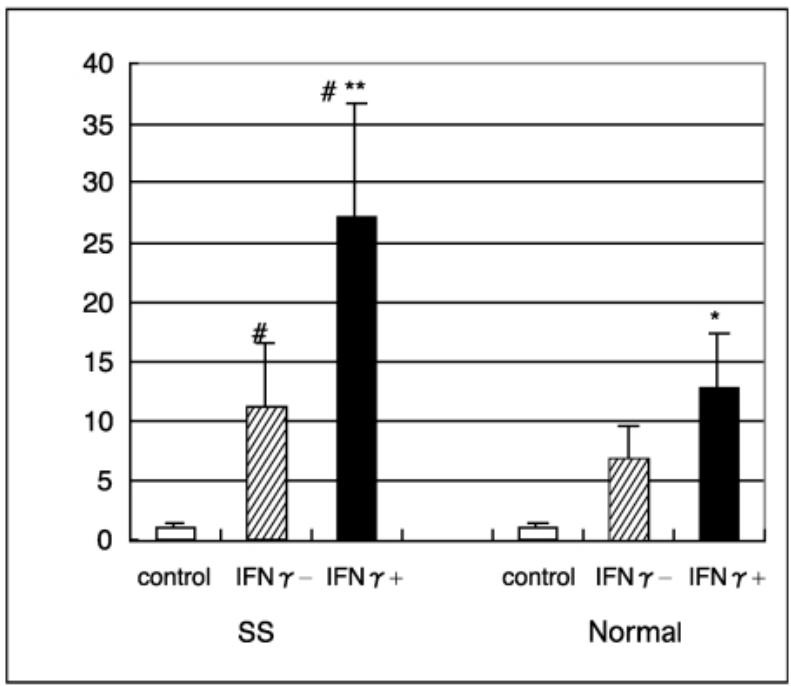

(a) Fas expression

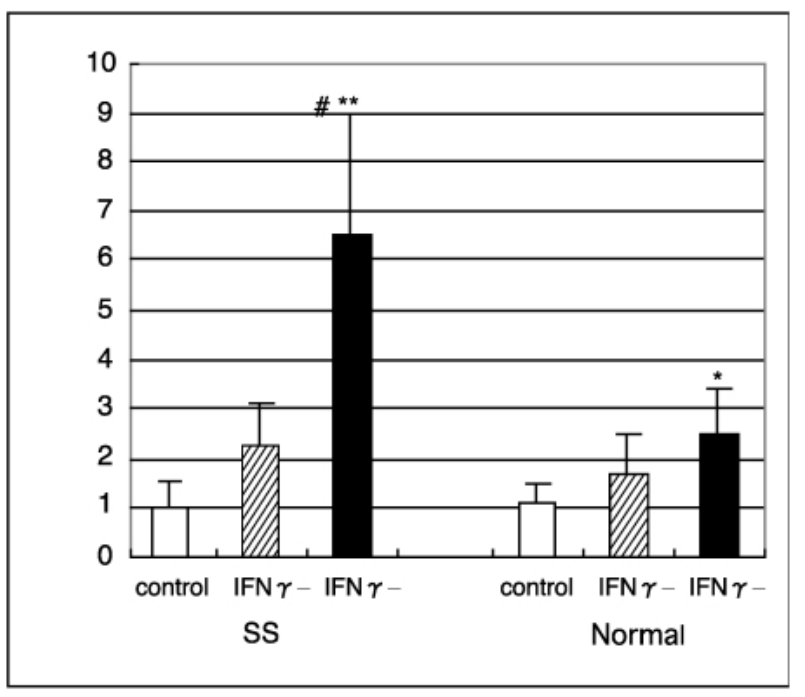

(b) CD40 expression

図 3 培養唾液腺上皮細胞における IFN $\gamma$ による(a) Fas お よび (b) CD40 発現の誘導

SS 15 例, 正常 10 例にて検討した結果を示す. 唾液腺上 皮細胞を IFN $\gamma(1000 \mathrm{U} / \mathrm{ml})$ の存在抢よび非存在下で 72 時 間培養し，フローサイトメトリー法にて Fas および CD40 陽 性細胞（\%）の検討を行った．IFN $\gamma$ はSS 抢よび正常唾液 腺上皮細胞に扮いて両者の発現を有意に増強した $\left({ }^{*} \mathrm{P}<\right.$ $0.05,{ }^{* *} \mathrm{P}<0.01$ vs IFN $\gamma$-群). また Fas 発現は IFN $\gamma$ の有無 にかかわらずSSに拉いて正常と比べて増大しており（とも に\# $\mathrm{P}<0.05), \mathrm{CD} 40$ 発現は IFN $\gamma$ 刺激時において正常と比べ て有意に増大していた $(\# \mathrm{P}<0.05)$. Control：一次抗体 (isotype-matched）を用いた陰性コントロール.

は特に dence foci の部位でアポトーシス細胞が少な いこと，2）導管上皮, 腺房細胞および浸潤リンパ 球が Fas を発現しており, FasL は浸潤リンパ球の 一部が発現していること，3）大部分の浸潤リンパ 球が Bcl-2 を発現していることが判明した。これら より SS 唾液腺上皮細胞障害の一因として Fas/ FasL を介するアポトーシスが考えられること，ま 

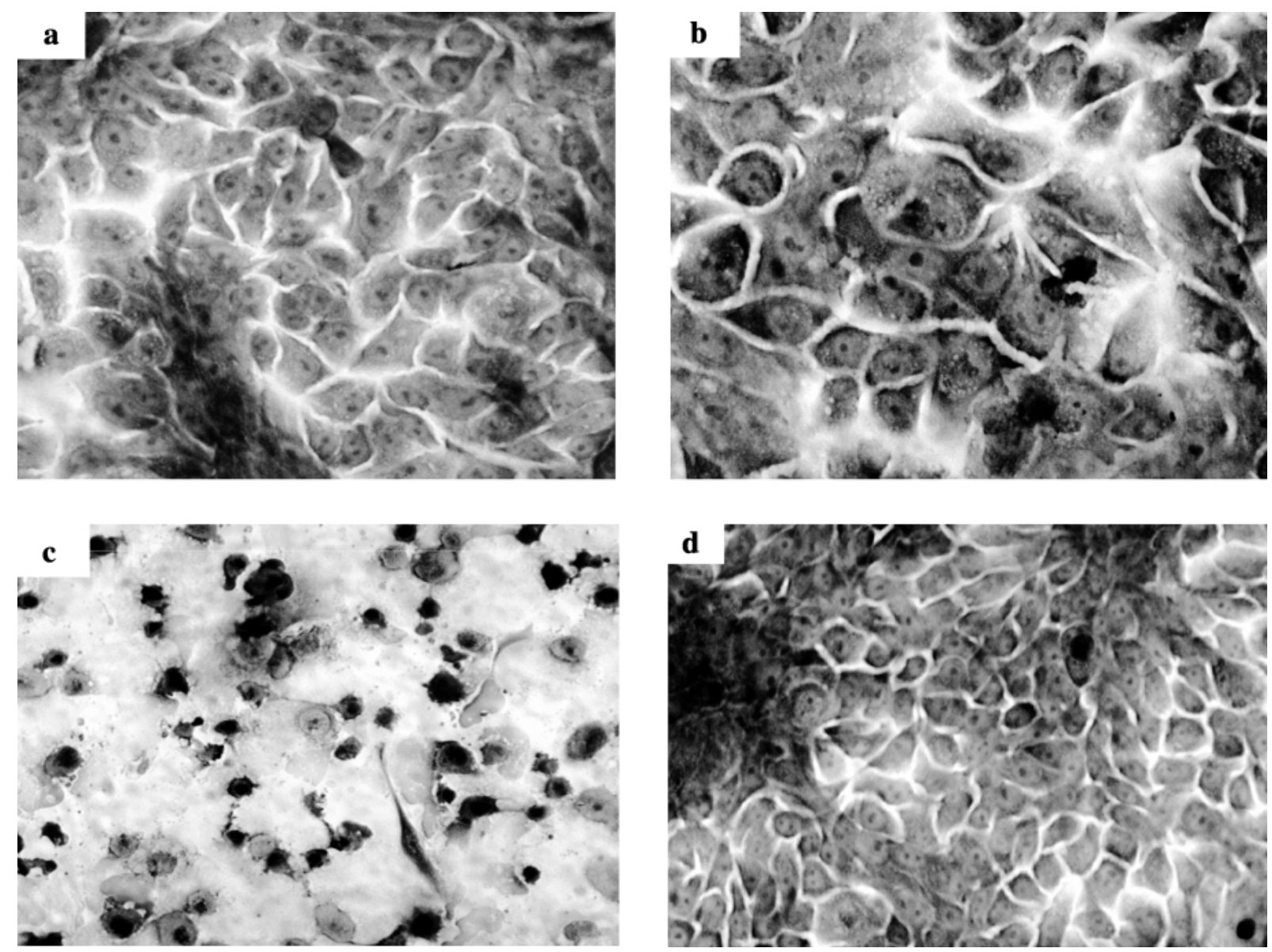

図 4 抗 Fas 抗体抢よび抗 CD40 抗体を用いた IFN $\gamma$ 刺激唾液腺上皮細胞に抢けるアポトーシス誘導

$\mathrm{SS}$ 唾液腺培養上皮細胞を a ) 培養液のみ, b ) IFN $\gamma(1000 \mathrm{U} / \mathrm{ml})$ で 72 時間刺激後, 抗 Fas 抗体 $(\mathrm{CH} 11,1 \mu \mathrm{g} / \mathrm{ml})$ を添加し 24 時間, c) IFN $\gamma(1000 \mathrm{U} / \mathrm{ml})$ で 72 時間刺激後, 抗 Fas 抗体 $(\mathrm{CH} 11,1 \mu \mathrm{g} / \mathrm{ml})$ 抢よび抗 CD40 抗体 $(5 \mathrm{C} 3,1 \mu \mathrm{g} / \mathrm{ml})$ を添加し 24 時間, d) IFN $\gamma(1000 \mathrm{U} / \mathrm{ml})$ で 72 時間刺激後, まず抗 Fas 中和抗体 (ZB4, $5 \mu \mathrm{g} / \mathrm{ml})$ を添加し, 1 時間後に抗 Fas 抗体 $(\mathrm{CH} 11,1 \mu \mathrm{g} / \mathrm{ml})$ 抢よび抗 CD40 抗体（5C3,1 $\mu \mathrm{g} / \mathrm{ml})$ を添加し 24 時間培養，細胞を May Grunwald Giemsa 染色して検鏡によ りアポトーシス細胞の解析を施行した。

IFN $\gamma$ 刺激 SS 唾液腺上皮細胞に抗 Fas 抗体 (CH11) と抗 CD40 抗体を同時添加した c) にのみアポトーシスが誘導されて抢り, d) では抗 Fas 中和抗体の添加によりアポトーシスが抑制されている.

た Fas 陽性の活性化した唾液腺浸潤リンパ球が Bcl-2 によりアポトーシスを回避して生存し，病態 の形成，進展に関与していることが示唆された。

以上の知見を踏まえ, SS 唾液腺上皮細胞のアポ トーシス機構をさらに解析するために口唇小唾液腺 生検組織より得た培養唾液腺上皮細胞を用いて in vitroにおける上皮細胞のアポトーシスの検討を行 つた23).

まず IFN $\gamma$ を用いて培養上皮細胞を刺激し，細胞 死に関与する可能性のある細胞表面機能分子の発現 を検討した。その結果, SS 唾液腺上皮細胞は無刺 激の状態で Fas を発現しており，IFN $\gamma$ 刺激は Fas 発現をさらに増強した。 Fas 発現は IFN $\gamma$ の刺激, 非刺激にかかわらず正常細胞より有意に増大してい た $(\mathrm{P}<0.05$, 図 3a)。 また細胞表面機能分子のう ち, CD40 は IFN $\gamma$ 刺激により発現が有意に増大し
た（図 $3 b)$ ，結果は割愛するが，IFN $\gamma$ 刺激により CD80 および CD86 発現は著変を認めなかつた.

IFN $\gamma$ 刺激により SS 唾液腺上皮細胞の Fas 発現 が増大することが判明したため，この状態において 抗 Fas 抗体（CH11）を添加し，アポトーシスが誘 導されるかどうか検討した（図 4, 5). 意外なこと に細胞表面に充分量の Fas を発現しているにもか かわらず，この条件下では SS 唾液腺上皮細胞にア ポトーシスは誘導されなかった（図 4b). そこで $\mathrm{SS}$ 唾液腺上皮細胞のアポトーシスに Fas 以外の分 子が関与している可能性を考慮し, IFN $\gamma$ 刺激にて 発現が増大するCD40 に対する抗体（5C3）を抗 Fas 抗体と同時に IFN $\gamma$ 刺激 SS 唾液腺上皮細胞に 添加した. その結果, 多くの上皮細胞にアポトーシ スが誘導された (図 4c). IFN $\gamma$ 非刺激の SS 唾液腺 上皮細胞に抗 Fas 抗体と抗 CD40 抗体を同時に添 
加してもアポトーシスは誘導されなかった。

CD40 は B リンパ球上に発現している細胞表面機 能分子の一つであり，主に細胞死を抑制するシグナ ル伝達に関与している。CD40 は種々の上皮細胞に も発現が認められており，未だその機能は充分解明 されていないが，例えば肝細胞では細胞死を誘導す るシグナル伝達に関与すると報告されている54).

$\mathrm{SS}$ 唾液腺上皮細胞死に Fas または CD40 のどち らのシグナルがより重要であるかを決定するために Fas に対する中和抗体（ZB4）を用いて検討した. その結果, ZB4 は IFN $\gamma$ 刺激 SS 唾液腺上皮細胞に 抗 Fas 抗体と抗 CD40 抗体を添加して誘導される アポトーシスをほぼ完全に抑制した（図 4d）。この 結果より SS 唾液腺上皮細胞に誘導される細胞死が 主にFas を介することおよび CD40を介するシグ ナルはFas のシグナルを促進することにより作用 していることが示唆された。 以上の結果はDNA fragmentation assay にても確認された（図 5).

Fas を介した死の経路にはさまざまな細胞死調節 分子が関与している. これら分子を検討したところ,

IFN $\gamma$ 刺激 SS 唾液腺上皮細胞に抗 CD40 抗体を作 用させると細胞死抑制蛋白である cellular FLICEinhibitory protein (c-FLIP) の発現が抑制されるこ

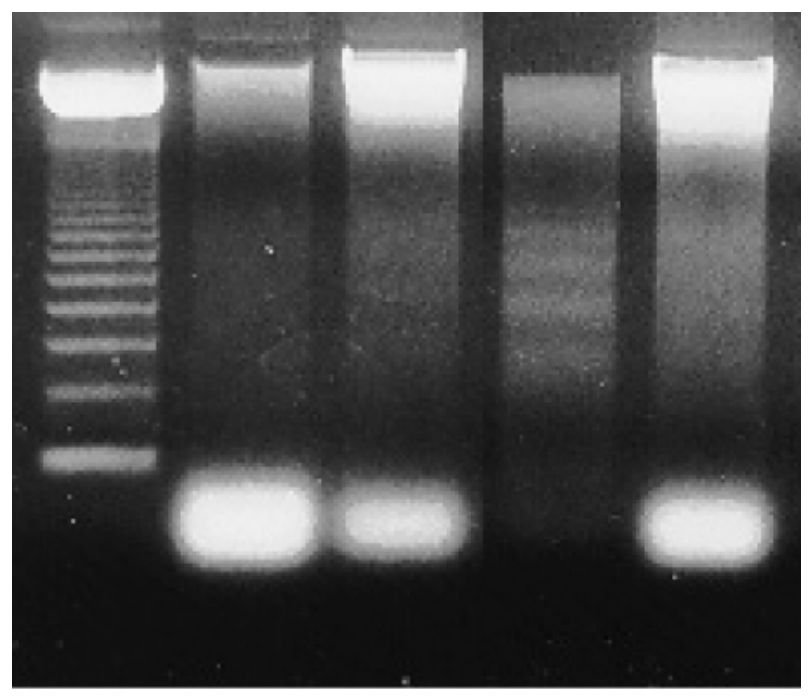

\section{$\begin{array}{lllll}M W & 1 & 2 & 3 & 4\end{array}$}

図 5 抗 Fas 抗体抢よび抗 CD40 抗体を用いた IFN $\gamma$ 刺激唾 液腺上皮細胞に打けるアポトーシス誘導（DNA fragmentation assay)

図 4 と同様のサンプルを DNA fragmentation assayにより 検討した. IFN $\gamma$ 刺激した SS 唾液腺上皮細胞を抗 Fas 抗体 $(\mathrm{CH} 11,1 \mu \mathrm{g} / \mathrm{ml})$ および抗 CD40 抗体 $(5 \mathrm{C} 3,1 \mu \mathrm{g} / \mathrm{ml})$ にて 処理した細胞のみに（lane 3）に明瞭な DNA ladder を認め る.
とが判明した（図 6）。c-FLIP は dominant negative 効果により caspase-8 が death-inducing signaling complex (DISC) に結合することを阻害するこ とにより Fas シグナルを抑制する. c-FLIP が唾液 腺上皮細胞に構成的に発現していることは既に報告 されており55)，興味深い知見である.

$\mathrm{SS}$ 唾液腺上皮細胞と正常唾液腺上皮細胞は Fas および CD40 発現量の違いが認められたが, in vitro の系では同じ条件下においてアポトーシス誘 導に顕著な違いは認められなかった。正常唾液腺に はリンパ球浸潤がなく，すなわち IFN $\gamma$ 等のサイト カインやFas, CD40 に対するリガンドを持った細 胞が存在しないため上皮細胞のアポトーシスが誘導 されないと考えられる。

おわりに

以上より，現時点における SS 唾液腺組織障害の 分子機構の一つの仮説として以下が想定される（図 7a, b). CXCR4 陽性のナイーブ $\mathrm{T}$ 細胞は血管内皮 細胞などに発現する SDF-1 との相互作用を介し て, 唾液腺内を巡回し免疫学的監視を行っている. 何らかの機序により唾液腺導管上皮細胞に自己抗原 が発現され，これを自己反応性 $\mathrm{T}$ 細胞が認識する ことにより自己免疫反応が開始される. 自己抗原認 識により活性化した一部の $\mathrm{T}$ 細胞が IFN $\gamma$ を分泌 し, 導管上皮細胞に HLA-DR 発現を誘導し, また IP-10, Mig, I-TAC を産生させる. 同時に IFN $\gamma$ は $\mathrm{T}$ 細胞自身に作用し， CXCR3 の発現を増強させる.

\section{c-FLIP}

FADD

$B c \mid-x L$ $\beta$-actin

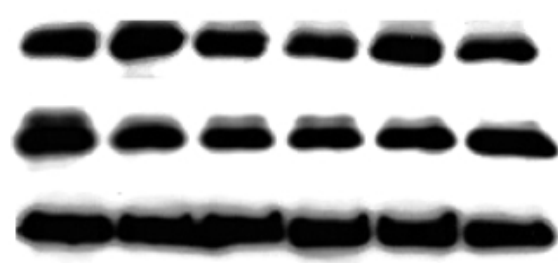

\section{$\begin{array}{llllll}1 & 2 & 3 & 4 & 5 & 6\end{array}$}

図 6 抗 CD40 抗体による IFN $\gamma$ 刺激唾液腺上皮細胞に抢け る c-FLIP 発現抑制

$\mathrm{SS}$ 唾液腺培養上皮細胞を 1）培養液のみ， 2) IFN $\gamma(1000$ $\mathrm{U} / \mathrm{ml})$ で 72 時間刺激， 3)-6)は IFN $\gamma(1000 \mathrm{U} / \mathrm{ml})$ で 72 時 間刺激後, 抗 CD40 抗体 $(5 \mathrm{C} 3,1 \mu \mathrm{g} / \mathrm{ml})$ を 3) 12 時間, 4) 24 時間，5）48 時間，6） 72 時間培養しウエスタンブロット 法にて c-FLIP, FADD および Bcl-xL 蛋白の発現を検討した.

抗 CD40 抗体刺激後, 時間経過とともに c-FLIP の発現抑 制が認められる。同時に解析した FADD および Bcl-xL 発現 は著変を認めない。 

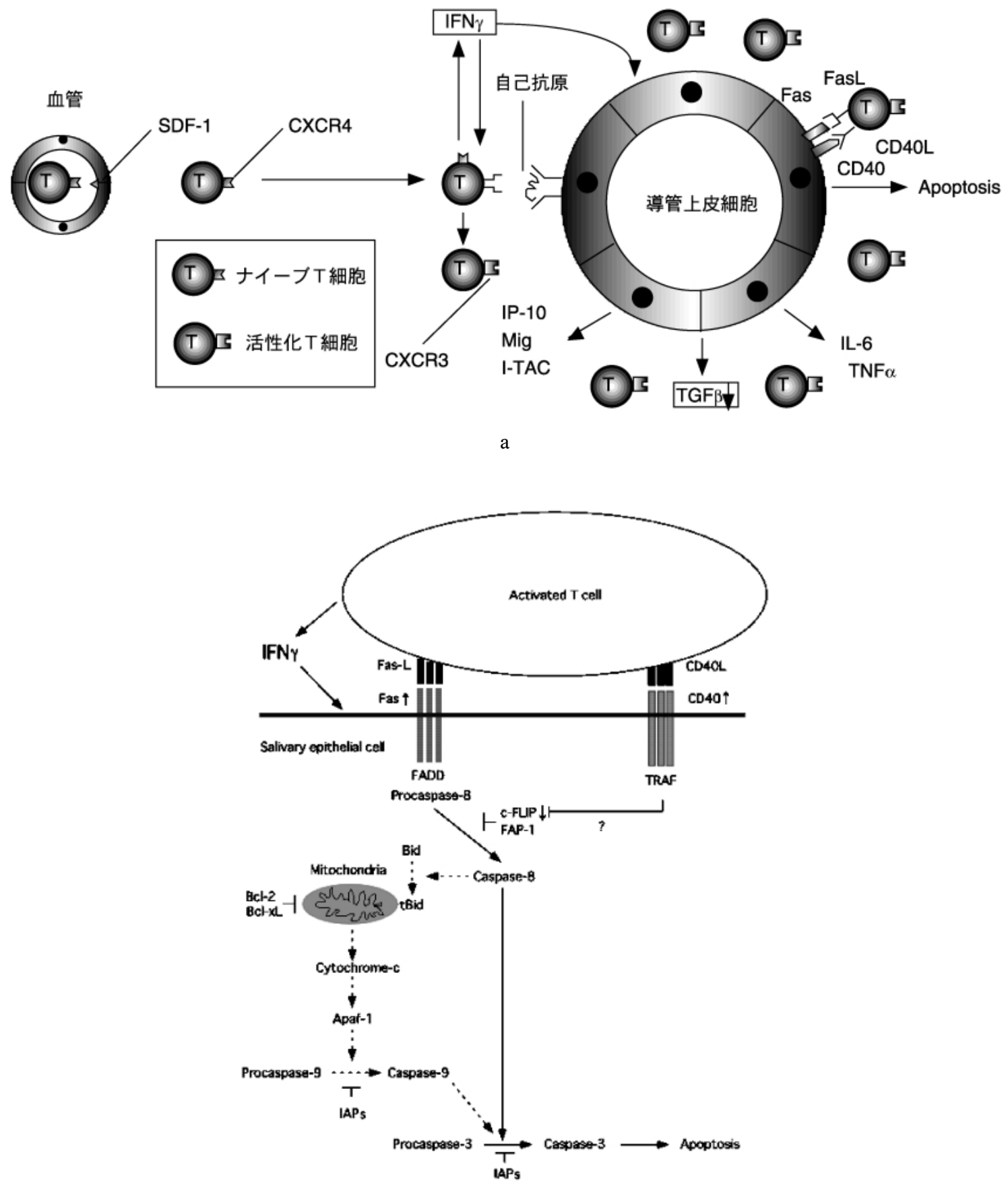

b

図 7a,b SS 唾液腺組織障害の分子機構（仮説） 説明は本文参照.

$\mathrm{IFN} \gamma$ の産生には上皮細胞からの $\mathrm{TGF} \beta$ の産生減少 が関与しているものと考えられる。このようにして サイトカインとケモカインの相互作用により, 細胞 浸潤が持続的に形成される（図 7a).

一方，浸潤リンパ球より分泌された IFN $\gamma$ により 上皮細胞は Fas および CD40を細胞表面上に発現 する。ここに FasL および CD40L を発現した活性 化 $\mathrm{T}$ 細胞が結合すると CD40 からの刺激が c-FLIP 発現を抑制し，上皮細胞にFas 介介するア゚トー
シスが誘導される（図 7b)。CD40 からのシグナル が c-FLIP 発現を抑制するメカニズムは今のところ 不明である，著者らの検討では，上皮細胞にこれら のリガンドは発現しないことが示されており, 上皮 細胞同士が相互作用することによってアポトーシス が誘導される可能性は低いと考えている.

将来的には上述の分子機構が解明され, 新しい SS に対する治療が開発されることが望ましい。一 方では唾液腺機能が廃絶した症例に対する対策が急 
務であり，現在著者らは唾液腺の再生医療の可能性 を模索している.

\section{文献}

1）小川法良, 菅井 進：リウマチ性疾患の疫学 像，シェーグレン症候群。リウマチ科 24 : 254-261, 2000.

2）小川法良, 菅井 進: 膠原病と合併症, シ エーグレン症候群。総合臨床 51 : 2149-2154, 2002.

3）小川法良，菅井 進：シェーグレン症候群の 新治療薬，アセチルコリンレセプター刺激 薬. リウマチ科 $24: 451-453,2000$.

4）小川法良, 下山久美子, 唐澤博美, 他： シ エーグレン症候群患者の口腔乾燥症状に対す る塩酸セビメリンの有用性の検討. 日本臨床 免疫学会雑誌 $27: 330-337,2004$.

5）小川法良：シェーグレン症候群。一診断のポ イントとベストの治療ガイドライン一. 内科 93 : 254-258, 2004.

6）小川法良：Sjögren 症候群の治療.内科 89 : 288-293, 2002.

7) Skopouli FN, Moutsopoulos HM : Cytokines in Sjögren's syndrome. Arch Med Intern 146 : 219-222, 1995.

8) Bacman S, Sterin-Borda L, Jose Camusso J, et al. : Circulating antibodies against rat parotid gland M3 muscarinic receptors in primary Sjögren's syndrome. Clin Exp Immunol 104 : 454-459, 1996.

9) Tsubota K, Hirai S, King LS, et al. : Defective cellular trafficking of lacrimal gland aquaporin5 in Sjögren's syndrome. Lancet 357 : 688-689, 2001.

10) Goicovich E, Molina C, Perez P, et al. : Enhanced degradation of proteins of the basal lamina and stroma by matrix metalloproteinases from the salivary glands of Sjögren's syndrome patients. Arthritis Rheum 48 : 2573-2584, 2003.

11) Oxholm P, Daniels TE, Bendtzen K : Cytokine expression in labial salivary glands from patients with primary Sjögren's syndrome. $A u$ toimmun 12 : 185-191, 1992.

12) Fox RI, Kang HI, Ando D, et al. : Cytokine mRNA expression in salivary gland biopsies of Sjögren's syndrome. J Immunol 152 : 55325539, 1994.

13) Ogawa N, Dang H, Lazaridis K, et al. : Analysis of transforming growth factor $\beta$ and other cytokines in autoimmune exocrinopathy
(Sjögren's syndrome). J Interferon Cytokine Research 15 : 759-767, 1995.

14) Boumba D, Skopouli FN, Moutsopoulos HM : Cytokine mRNA expression in the labial salivary gland tissues from patients with primary Sjögren's syndrome. Br J Rheumatol 34 : 326333, 1995.

15) Ohyama $Y$, Nakamura $S$, Matsuzaki G, et al. : Cytokine messenger RNA expression in the labial salivary glands of patients with Sjögren's syndrome. Arthritis Rheum 39:1376-1384, 1996.

16) Sun D, Emmert-Buck R, Fox PC : Differential cytokine mRNA expression in human labial minor salivary glands in primary Sjögren's syndrome. Autoimmun 28 : 125-137, 1998.

17) Konttinen YT, Kemppinen $\mathrm{P}$, Koski $\mathrm{H}$, et al. : TH1 cytokines are produced in labial salivary glands in Sjögren's syndrome, but also in healthy individuals. Scand J Rheumatol 28 : 106-112, 1998.

18) Fox PC, Brennan M, Sun PD : Cytokine expression in human labial minor salivary gland epithelial cells in health and disease. Arch Oral Biol 44 : S49-S52, 1999.

19) Kulkarni AB, Ward JM, Yaswan L, et al. : Transforming growth factor-beta 1 null mice. An animal model for inflammatory disorders. Am J Pathol 146 : 264-275, 1995.

20) Dang H, Geiser AG, Letterio JJ, et al. : SLElike autoantibodies and Sjögren's syndromelike lymphoproliferation in TGF-beta knockout mice. J Immunol 155 : 3205-3212, 1995.

21) Nakabayashi T, Letterio JJ, Geiser AG, et al. : Up-regulation of cytokine mRNA, adhesion molecule proteins, and MHC class II proteins in salivary glands of TGF $\beta 1$ knockout mice. $J$ Immunol 158 : 5527-5535, 1997.

22) Brookes SM, Price EJ, Venables PJW, et al. : Interferon-gamma and epithelial cell activation in Sjögren's syndrome. $\mathrm{Br} J$ Rheumatol 34 : 226-231, 1995.

23) Ping L, Ogawa N, Sugai S. : Novel role of CD40 in Fas-dependent apoptosis of cultured salivary epithelial cells from patients with Sjögren's syndrome. Arthritis Rheum, in press, 2005.

24) Manoussakis MN, Dimitriou ID, Kapsogeorgou EK, et al. : Expression of B7 costimulatory molecules by salivary gland epithelial cells in patients with Sjögren's syndrome. Arthritis 
Rheum 42 : 229-239, 1999.

25）下山久美子：シェーグレン症候群（SS）唾液 腺上皮細胞における inducible nitric oxide synthase (iNOS) 発現と nitric oxide (NO) 産生. 金沢医科大学雑誌 $28: 224-230,2003$.

26) McCartney-Francis NL, Wahl SM. : Dysregulation of IFN- $\gamma$ signaling pathways in the $a b-$ sence of TGF- $\beta 1$. J Immunol 169 : 5941-5947, 2002.

27) Sankar V, Brennan MT, Kok MR, et al. : Etanercept in Sjögren's syndrome. A twelveweek randomized, double-blind, placebo-controlled pilot clinical trial. Arthritis Rheum 50 : 2240-2245, 2004.

28) Cuello C, Palladinetti P, Tedla N, et al. : Chemokine expression and leucocyte infiltration in Sjögren's syndrome. $\mathrm{Br} J$ Rheumatol 37 : 779-783, 1998.

29) Amft N, Curnow J, Scheel-Toellner D, et al. : Ectopic expression of the $\mathrm{B}$ cell-attracting chemokine BCA-1 (CXCL13) on endothelial cells and within lymphoid follicles contributes to the establishment of germinal center-like structures in Sjögren's syndrome. Arthritis Rheum 44 : 2633-2641, 2001.

30) Xanthou G, Polihronis M, Tzioufas AG, et al. : Lymphoid chemokine messenger RNA expression by epithelial cells in the chronic inflammatory lesion of the salivary glands of Sjögren's syndrome. Arthritis Rheum 44 : 408-418, 2001.

31) Amft N, Bowman SJ. : Chemokines and cell trafficking in Sjögren's syndrome. Scand J Immunol 54 : 62-69, 2001.

32) Salomonsson $S$, Larsson $P$, Tengner $P$, et al. : Expression of the $\mathrm{B}$ cell-attracting chemokine CXCL13 in the target organ and autoantibody production in ectopic lymphoid tissue in the chronic inflammatory disease Sjögren's syndrome. Scand J Immunol 55 : 336-342, 2002.

33）小川法良：シェーグレン症候群とケモカイ ン. 臨床免疫 $38:$ 141-146, 2002.

34) Ogawa N, Ping L, Zhenjun L, et al. : Involvement of IFN $\gamma$-induced $\mathrm{T}$ cell-attracting chemokines, IFN $\gamma$-inducible protein of 10 $\mathrm{kDa}$; IP-10 (CXCL10) and monokine induced by IFN $\gamma$; Mig (CXCL9) in the salivary gland lesions of Sjögren's syndrome. Arthritis Rheum 46 : 2730-2741, 2002.

35) Ogawa N, Kawanami T, Shimoyama K, et al. : Expression of I-TAC (interferon-inducible $\mathrm{T}$ cell $\alpha$ chemoattractant, CXCL11) in the saliva- ry glands of patients with Sjögren's syndrome. Clin Immunol 112 : 235-238, 2004.

36) Ogawa N, Dang H, Talal N. : Apoptosis and autoimmunity. J Autoimmun 8 : 1-19, 1995.

37）小川法良：アポトーシスと自己免疫. 炎症と 免疫 $5: 462-469,1996$.

38) Kong L, Ogawa N, Nakabayashi T, et al. : Fas and Fas ligand expression in the salivary glands of patients with primary Sjögren's syndrome. Arthritis Rheum 40 : 87-97, 1997.

39) Kong L, Ogawa N, McGuff HS, et al. : Bcl-2 family expression in salivary glands from patients with primary Sjögren's syndrome. Involvement of Bax in salivary gland destruction. Clin Immunol Immunopathol 88:133-141, 1998.

40) Polihronis M, Tapinos NI, Theocharis SE, et al. : Modes of epithelial cell death and repair in Sjögren's syndrome. Clin Exp Immunol 114 : 485-490, 1998.

41) Matsumura R, Umemiya K, Kagami M, et al. : Glandular and extraglandular expression of the Fas-Fas ligand and apoptosis in patients with Sjögren's syndrome. Clin Exp Rheumtol 16 : 561-568, 1998.

42) Ogawa N, Dang H, Kong L, et al. : Lymphocyte apoptosis and apoptosis-associated gene expression in Sjögren's syndrome. Arthritis Rheum 39 : 1875-1885, 1996.

43) Ogawa N, Karahashi T, Akamine N, et al. : Activation-induced cell death of peripheral blood $\mathrm{T}$ lymphocytes in patients with primary Sjögren's syndrome. Jpn J Rheumatol 9 : 245258, 1999.

44) Zeher M, Szodoray P, Gyimesi E, et al. : Correlation of increased susceptibility to apoptosis of $\mathrm{CD} 4+\mathrm{T}$ cells with lymphocyte activation and activity of disease in patients with primary Sjögren's syndrome. Arthritis Rheum 42 : 1673-1681, 1999.

45) Humphreys-Beher MG, Peck AB, Dang H, et al. : The role of apoptosis in the initiation of the autoimmune response in Sjögren's syndrome. Clin Exp Immunol 116 : 383-387, 1999.

46) Patel YI, McHugh NJ. : Apoptosis-new clue to the pathogenesis of Sjögren's syndrome. Rheumatology (Oxford) 39 : 119-121, 2000.

47) Manganelli, P., Fietta, P.: Apoptosis and Sjögren's syndrome. Seminars Arthritis Rheum 33 : 49-65, 2003.

48）大橋弘幸, 小川法良：シェーグレン症候群患 
者リンパ球における Fas 抗原, bcl-2 の発現 の検討. 日本臨床 $53: 2451-2455,1995$.

49）小川法良：Sjögren 症候群におけるアポトー シス異常. 医学のあゆみ 178 : 401-404, 1996.

50）小川法良：Sjögren 症候群。医学のあゆみ 182 : 693-697, 1997.

51）小川法良, 大橋弘幸：Sjögren 症候群におけ るアポトーシス。臨床病理 45:643-648, 1997.

52）小川法良：膠原病患者末梢血 $\mathrm{T}$ 細胞の活性化 誘導細胞死（AICD）の意義. 医学のあゆみ 190 : 838-839, 1999.

53）小川法良：病態とアポトーシス, シェーグレ ン症候群. 臨床免疫 38 増刊, アポトーシス
のすべて : 380-385, 2002.

54) Afford SC, Randhawa S, Elipoulos AG, et al. : CD40 activation induces apoptosis in cultured human hepatocytes via induction of cell surface Fas ligand expression and amplifies Fas-mediated hepatocyte death during allograft rejection. J Exp Med 189 : 441-446, 1999.

55) Abu-Helu RF, Dimitriou ID, Kapsogeorgou EK, et al. : Induction of salivary gland epithelial cell injury in Sjögren's syndrome : in vitro assessment of $\mathrm{T}$ cell-derived cytokines and Fas protein expression. J Autoimmun 17 : 141-153, 2001. 